\section{T. Methi \& P.M. Thorsby svarer:}

Vi takker Jarle Breivik for hans kommentar (1) til vår kronikk (2). Hvorvidt induksjon av insulinresistens som følge av kaloriforgiftning er en «evolusjonistisk adaptasjon» eller en «reaksjon» er ikke kronikkens hovedpoeng, men snarere om insulinresistens er en «defekt» ved type 2-diabetes, eller en ønsket respons fra kritiske organer med formål om å beskytte seg mot metabolsk stress. Insulinresistens som tilstand er etter vår mening dårlig patofysiologisk forklart, og de fremlagte hypotesene utfordrer det gjeldende paradigmet i så måte. Breivik gjengir oss ikke korrekt når han siterer oss på at energioverskudd er en situasjon menneskeheten sjelden har møtt på gjennom evolusjonen. Faktisk møter kroppens systemiske sirkulasjon et «energioverskudd» etter hvert måltid i form av postprandiale økninger i glukose, lipider og aminosyrer. Dette håndteres gjennom utskillelse av insulin, men også midlertidig insulinresistens i skjelett- og hjertemuskulatur. Denne fysiologiske adaptasjonen favoriserer energilagring i fettvev til senere bruk. Hypotesen er at denne induserte insulinresistensen også kan beskytte hjertemuskulaturen mot næringsindusert dysfunksjon (3-7). Det vi ikke er tilpasset til, og som vi sjelden har møtt på gjennom evolusjonen, er et vedvarende kalorioverskudd som går over mange år, og som kan resultere i type 2-diabetes. Breiviks argumenter er etter vår mening ikke nok til å forkaste hypotesen om at insulinresistens kan være en kronisk reaksjon på energioverskudd over tid, ganske enkelt fordi insulinresistens utvikles lenge før type 2-diabetes $(8,9)$. Vi har muligens feilaktig, fra et evolusjonsteoretisk ståsted, brukt ordet «adaptiv» i vår argumentasjon, men kroppen har også en rekke metthetsinduserende hormoner som beskytter mot overinntak av mat, f.eks. leptin som utskilles fra fettvev proporsjonalt i forhold til fettvevets masse. Hvis det er, som Breivik hevder, «ingen grunn til å tro at genene våre har blitt selektert for å motstå energioverskudd» er det vanskelig å forstå hvorfor fettcellene skulle produsere leptin, et hormon som gir metthetsfølelse, og dermed begrenser energioverskuddet.

\section{Trond Methi}

methi.trond@gmail.com

Per Medbøe Thorsby

Trond Methi (f. 1977) er farmasøyt, ph.d. og medisinsk rådgiver hos Lilly Diabetes.

Forfatter oppgir følgende interessekonflikter: Han er ansatt i Eli Lilly Norge.

Per Medbøe Thorsby (f. 1964) er ph.d. og seksjonsoverlege ved Hormonlaboratoriet, Oslo universitetssykehus.

Forfatteren oppgir følgende interessekonflikter: Han har mottatt honorar fra Norges diabetesforbund, SanofiAventis, Bristol-Myers Squibb, Statens legemiddelverk og Antidoping Norge.

\section{Litteratur}

1. Breivik J. Re: Insulinresistens - kroppens forsvar mot kaloriforgiftning? Tidsskr Nor Legeforen 2016; 136: 1185

2. Methi T, Thorsby PM. Insulinresistens - kroppens forsvar mot kaloriforgiftning? Tidsskr Nor Legeforen 2016: 136: 1015-7.

3. Nolan CJ, Ruderman NB, Kahn SE et al. Insulin resistance as a physiological defense against metabolic stress: implications for the management of subsets of type 2 diabetes. Diabetes 2015; 64: 673-86.

4. Taegtmeyer $\mathrm{H}$, Beauloye $\mathrm{C}$, Harmancey $\mathrm{R}$ et al. Insulin resistance protects the heart from fuel overload in dysregulated metabolic states. Am J Physiol Heart Circ Physiol 2013; 305: H1693-7.

5. Schenk S, Saberi M, Olefsky JM. Insulin sensitivity: modulation by nutrients and inflammation. J Clin Invest 2008; 118: 2992-3002.

6. Unger RH. Lipid overload and overflow: metabolic trauma and the metabolic syndrome. Trends Endocrinol Metab 2003; 14: 398-403.

7. Hoehn KL, Salmon AB, Hohnen-Behrens C et al. Insulin resistance is a cellular antioxidant defense mechanism. Proc Natl Acad Sci U S A 2009; 106: 17787-92.

8. Jallut D, Golay A, Munger R et al. Impaired glucose tolerance and diabetes in obesity: a 6-year follow-up study of glucose metabolism. Metabolism 1990; 39 : 1068-75.

9. Brands M, Swat M, Lammers NM et al. Effects of a hypercaloric diet on $\beta$-cell responsivity in lean healthy men. Clin Endocrinol (Oxf) 2013; 78: 217-25.

\section{Re: Tydeligere og bedre}

Sjefredaktøren i Tidsskriftet er fornøyd med en ny forankring av Tidsskriftets redaksjonelle integritet, og avslutter lederen med: «Det lover godt for et tillitsfullt forhold også i fremtiden, slik at norske leger kan fortsette å være stolte av et tidsskrift med tiltro både nasjonalt og internasjonalt» (1).

Lesing av samme nummer av Tidsskriftet gjør ordene hans til skamme. I en artikkel om nye fly i luftambulansetjenesten formidles en pressemelding fra Luftambulansetjenesten ANS omtrent uendret som et redaksjonelt produkt (2). Et raskt søk på internett ville ha vist forfatteren at dette vedtaket er sterkt omdiskutert, og at både Finnmarkssykehuset, Vest-Finnmark regionråd, Finnmark Legeforening, en rekke ordførere og brukere av tjenesten er svært bekymret fordi et propellfly erstattes med et jetfly som ikke kan lande på 8 av fylkets 11 flyplasser. Her er ikke én kritisk kommentar, ingen spørsmål, og kommentarene fra Helse Nords administrerende direktør og fra medisinsk rådgiver i Luftambulansetjenesten ANS er klippet direkte fra pressemeldingen fra Luftambulansetjenesten ANS (3). Kritisk journalistikk som støtter seg på Redaktørplakaten? Neppe.

Det er bra at Tidsskriftets redaksjonelle uavhengighet fra Legeforeningen er sikret. Da er det bare å begynne å bruke den for å oppnå «tiltro både nasjonalt og internasjonalt».

\section{Torben Wisborg}

torben@wisborg.net

Torben Wisborg (f. 1956) er overlege ved Finnmarkssykehuset, leder av Nasjonal Kompetansetjeneste for Traumatologi og professor ved Universitetet i Troms $\varnothing$.

Ingen oppgitte interessekonflikter.

\section{Litteratur}

1. Brean A. Tydeligere og bedre. Tidsskr Nor Legeforen 2016; 136: 977.

2. Fjellhaug MS. Jetfly i luftambulansetjenesten. Tidsskr Nor Legeforen 2016; 136 1031.

3. Luftambulansetjenesten ANS. www.luftambulanse.no/luftambulansetjenesten f\%C3\%A5r-jetfly-5 (24.6.2016).

\section{A. Brean svarer:}

Jeg takker Torben Wisborg for kommentaren til min lederartikkel (1). Hans kommentar gjelder en artikkel opprinnelig publisert på legejobber.no, Tidsskriftets stillingsportal på nett (2). Artikkelen ble gjengitt i Tidsskriftets papirutgave nr. 11/2016, under legejobber.no sine faste sider. Det oppgis tydelig i artikkelens første avsnitt at den bygger på en pressemelding fra Luftambulansetjenesten. Slik Wisborg anfører er det aktuelle vedtaket omstridt i regionen. Men omstridt er likevel ikke det samme som feilaktig. Det er i de berørte områder i nord delte meninger om vedtaket (3). Sett i retrospekt burde vi fremhevet dette bedre i artikkelen på legejobber.no. Saken viser, slik Wisborg fortjenestefullt påpeker, at det er behov for å klargjøre skillet mellom de ulike typer innhold i Tidsskriftet, spesielt i papirutgaven. Vi lover å ta lærdom av dette.

Debatten om Luftambulansetjenestens dekning i nord er interessant for Tidsskriftets lesere. Wisborgs innlegg viser at saker som løftes frem i Tidsskriftet blir lagt merke til. Vi imøteser gjerne en kommentarartikkel som redegjør for argumentene mot det aktuelle vedtaket.

\section{Are Brean}

are.brean@tidsskriftet.no

Are Brean (f. 1965) er sjefredaktør i Tidsskriftet.

Ingen oppgitte interessekonflikter. 